\title{
EVALUATION OF THE RELATIONSHIP BETWEEN VIRULENCE, ANTIBIOTIC RESISTANCE GENES AND DEVELOPMENT OF BIOFILM IN ESCHERICHIA COLI ISOLATED FROM BROILER CHICKEN
}

\author{
MARAM, M. TAWAKOL ${ }^{1}$ and AHLAM, E. YOUNIS. ${ }^{2}$ \\ ${ }^{1}$ Reference Laboratory for Veterinary Quality Control on Poultry Production, Gamasa, \\ Animal Health Research Institute. \\ ${ }^{2}$ Reference Laboratory for Veterinary Quality Control on Poultry Production, Damanhour, \\ Animal Health Research Institute.
}

Received: 31 March 2019; Accepted: 9 April 2019

\begin{abstract}
A total of 100 diseased broiler chickens of average age 22-28 days old were collected from different farms located in Dakahlia Governorate. All samples were subjected to clinical and postmortem (P.M) examination as well as bacteriological examination for detection of infection. Thus, E. coli was recovered from examined organs of 37 chickens with an incidence rate of $37 \%$ (37 out of 100). Accuratly, 10 E. coli serogroupes were identified in 28 positive samples and the most predominant serogroup were $\mathrm{O}_{125} 16 \%, \mathrm{O}_{91} 14 \%, \mathrm{O}_{1} 11 \%, \mathrm{O}_{26}$ $\mathrm{K}_{60} 11 \%$ \& $\mathrm{O}_{86} \mathrm{~K}_{64} 8 \& \mathrm{O}_{128} 5 \%$ \& $\mathrm{O}_{55} \mathrm{~K}_{59} 3 \%$ \& $\mathrm{O}_{166} 3 \%$ \& $\mathrm{O}_{103} 3 \%$ and $\mathrm{O}_{144} 3 \%$ and untypable E. coli (24 $\%)$. Studying antibiogram resistance pattern of $E$. coli isolates revealed that all isolates demonstrated multidrug resistence pattern. The highest resistance rates were recorded against Lincomycin (100\%) and lowest are Colistin (7.14\%) and other tested antibiotics showed variations regarding their resistance patterns. The most predominant serotypes of this study have the ability to form biofilm on the inner wall of the glass. PCR was done for detection of resistant genes (bla and $f i m \mathrm{H}$ ) in the 10 tested isolated serotypes and the results revelead that, $100 \%$ and $90 \% \& 100 \%, 90 \%, 90 \%$ and $100 \%$ were positive for resistant genes and virulence genes, respectively and investigate the relationship between them was discovered. By studying the effect of Olive Leaf Extract on multidrug resistant isolates, results were revealed that all tested serotypes are sensitive to Olive Leaf Extract (10\% conc.).
\end{abstract}

Key words: E coli, resistant to antibiotic, resistant genes, virulent genes, biofilm, olive leaf extract.

\section{INTRODUCTION}

Avian colibacillosis caused by $E$. coli is serious infectious disease occurring in different types of chicken resulting in a significance losses in poultry industry. Escherichia coli $(E$. coli) is one of the normal bacterial flora in the gastrointestinal tract of poultry. About $10-15 \%$ of the intestinal coliforms in chickens are of pathogenic serotypes. Colisepticemia, respiratory tract infections, poultry cellulitis, swollen head syndrome, omphalitis/yolksac infection, pericarditis, peritonitis and salpangitis are important diseases caused by $E$. coli in birds Barnes et al. (1999). Escherichia coli recognized as major pathogen for public health problems in developing countries and represents leading etiological agent of diarrhea where several classes of enterovirulent $E$. coli, namely enterotoxigenic $E$. coli

Corresponding author: Dr. MARAM, M. TAWAKOL

E-mail address: maram_salah82@hotmail.com

Present address: Reference Laboratory for Veterinary Quality Control on Poultry Production, Gamasa, Animal Health Research Institute.
(ETEC), enteropathogenic E. coli (EPEC), enterohaemorrhagic $E$. coli (EHEC), enteroinvasive E. coli (EIEC), enteroaggregative E. coli (EAggEC), diarrhoea-associated haemolytic E. coli and cytolethal distending toxin (CLDT)-producing E. coli have been recognized by Nataro and Kaper (1998). The term biofilm is used to describe matrixenclosed bacterial population adherent to each other and/or to surfaces Costerton et al. (1995). E. coli is one of many bacteria that can switch between planktonic form and biofilm form. Several reasons can explain the need of bacteria to create biofilm, in this way bacteria can avoid being washed away by water flow or, cells in biofilms are about 1000 times more resistant than their planktonic Jefferson, (2004). Several surface organelles, including various types of fimbriae, autotransporter proteins and extracellular polysaccharides, have been found to facilitate or enhance biofilm formation of E. coli, largely depending on the environmental conditions and the particular strains studied Schembri et al. (2002) which may be resistant to antibiotic or not. The aim of this study is to evaluate the relationship between virulence, antibiotic resistance genes and 
development of biofilm in $E$. coli isolated from broiler chicken farms in Dakahlia Governorate in Egypt.

\section{MATERIALS AND METHODS}

A total of 100 diseased broiler chickens of average age 22-28 days old were collected from different farms located in Dakahlia Governorate were subjected to clinical and postmortem (P.M) examination as well as for isolation and identification of $E$. coli from tissue samples including liver, caecum, spleen, lungs, kidneys and heart according to Maram, (2014).

1. Detection of Escherichia coli by conventional method: was done according to Swayne et al. (1998) and Quinn et al. (2002).

1.1. Selective enrichment of E. coli in broth:

Each sample was inoculated separately into buffer peptone water were incubated at $37^{\circ} \mathrm{C}$ for $24 \mathrm{hrs}$ under aerobic condition.

1.2. Colonization of E. coli on selective differential solid media:

A loopful from the broth of each sample was streaked onto MacConkey's agar and Eosin Methylene Blue agar. The inoculated plates were incubated at $37{ }^{\circ} \mathrm{C}$ for 24 hours. Suspected E. coli colonies were purified and kept for further identification.

1.3. Identification of suspected E. coli colonies was done according to Quinn et al. (2002).

Culture characters, Microscopic examination and motility: were done according to Cruickshank et al. (1975)

\section{Biochemical Identification of E. coli:}

It was done according to Quinn et al. (2002) on indole reaction, methyl red test, voges proskauer test, citrate utilization test, catales test, sugar fermentation test, oxidase test, triple sugar iron and christener's urea agar test.

3. Serological identification of E. coli isolates was carried out according Edwards and Ewing (1972):

The obtained isolates were serogrouped in Animal Health Research Institute, Dokki, Giza using: Sifin antisera "Berlin, Germany" Polyvalent and monvalent diagnostic E. coli antisera.

\section{Sensitivity of E. coli isolates to antimicrobial agents:}

E. coli strains were tested for their antimicrobial sensitivity to various antibiograms (Amoxicillin, Enrofloxacin, Tetracycline, Doxycycline, Ampicillin, Flumequine, Gentamycin, Naldixic acid, Chloramphenicol, Erythromycin, Ciprofloxacin,
Lincomycin and Colistin) by the agar disc diffusion method according to finegold and martin (1982) and interpretation of the results according to CLSI (2016)

\section{Biofilm formation of E. coli:}

According to Maram, (2011); it was done on 10 serotyped $E$. coli isolates represents to serotypes detected. A loopful of tested organisms was inoculated in $10 \mathrm{~mL}$ of trypticase soya broth with $1 \%$ glucose in test tubes. The tubes were incubated at $37^{\circ} \mathrm{C}$ for 24 hours. One $\mathrm{ml}$ from the inoculated broth was transferred into another tube containing 4 $\mathrm{ml}$ trypticase soy broth with $1 \%$ glucose, one tube used as a control negative (not inoculated) and another tube was inoculated with $E$. coli (positive control). All test tubes were incubated at $37^{\circ} \mathrm{C}$ for 5 days. After incubation, tubes were decanted and washed with phosphate buffer saline $(\mathrm{pH} 7.3)$ and dried. Tubes were then stained with crystal violet $(0.1 \%)$. Excess stain was washed with deionized water. Tubes were dried in inverted position. The results of tube method were compared with the control positive strain. Biofilm formation was considered positive when a visible film lined the wall and the bottom of the tube. The experiment was performed in triplicate and repeated three times.

6. Molecular detection of $E$. coli resistant and virulence genes using Polymerase chain reaction (PCR):

\subsection{DNA extraction}

DNA extraction from $10 \mathrm{E}$. coli isolates represented 10 serotypes detected was performed using the QIAamp DNA Mini kit (Qiagen, Germany, GmbH) with modifications from the manufacturer's recommendations. Briefly, $200 \mu \mathrm{l}$ of the sample suspension was incubated with $10 \mu$ l of proteinase $\mathrm{K}$ and $200 \mu \mathrm{l}$ of lysis buffer at $56^{\circ} \mathrm{C}$ for $10 \mathrm{~min}$. After incubation, $200 \mu 1$ of $100 \%$ ethanol was added to the lysate. The sample was then washed and centrifuged following the manufacturer's recommendations. Nucleic acid was eluted with $100 \mu$ l of elution buffer provided in the kit.

6.2. Oligonucleotide Primer: Primers used were supplied from Metabion (Germany) are listed in Table (1).

6.3. $P C R$ amplification: Primers were utilized in a $25 \mu \mathrm{l}$ reaction containing $12.5 \mu \mathrm{l}$ of DreamTaq Green PCR Master Mix (2X) (Thermo Scientific), 1 $\mu 1$ of each primer of $20 \mathrm{pmol}$ concentration, $4.5 \mu 1$ of water, and $6 \mu \mathrm{l}$ of DNA template. The reaction was performed in an Applied biosystem 2720 thermal cycler. 
6.4. Analysis of the PCR Products:

The products of PCR were separated by electrophoresis on 1\% agarose gel (Applichem, Germany, $\mathrm{GmbH}$ ) in $1 \mathrm{x}$ TBE buffer at room temperature using gradients of $5 \mathrm{~V} / \mathrm{cm}$. For gel analysis, $20 \mu \mathrm{l}$ of the PCR products were loaded in each gel slot. Gelpilot 100 bp, 100 bp plus plus
DNA Ladders (Qiagen, Germany, GmbH), generuler 100 bp ladder (Fermentas, Thermo) and Genedirex 100 bp DNA ladder H3 RTU, Cat. No. DM003R500 were used to determine the fragment sizes. The gel was photographed by a gel documentation system (Alpha Innotech, Biometra) and the data was analyzed through computer software.

Table 1: Primers sequence, target genes, amplicon sizes and cycling conditions.

\begin{tabular}{|c|c|c|c|c|c|c|c|c|}
\hline \multirow{2}{*}{$\begin{array}{l}\text { Target } \\
\text { gene }\end{array}$} & \multirow{2}{*}{$\begin{array}{c}\text { Primers } \\
\text { sequences } \\
5^{\prime}-3^{\prime}\end{array}$} & \multirow{2}{*}{$\begin{array}{c}\text { Amplified } \\
\text { segment } \\
\text { (bp) }\end{array}$} & \multirow{2}{*}{$\begin{array}{c}\text { Primary } \\
\text { denaturation }\end{array}$} & \multicolumn{3}{|c|}{ Amplification ( 35 cycles) } & \multirow{2}{*}{$\begin{array}{c}\text { Final } \\
\text { extension }\end{array}$} & \multirow{2}{*}{ Reference } \\
\hline & & & & $\begin{array}{c}\text { Secondary } \\
\text { denaturation }\end{array}$ & Annealing & Extension & & \\
\hline $\operatorname{adrA}$ & $\begin{array}{c}\text { ATGTTCCCA } \\
\text { AAAATAATG } \\
\text { AA } \\
\text { TCATGCCGC } \\
\text { CACTTCGGT } \\
\text { GC }\end{array}$ & 1113 & $\begin{array}{l}94^{\circ} \mathrm{C} \\
5 \mathrm{~min} .\end{array}$ & $\begin{array}{c}94^{\circ} \mathrm{C} \\
30 \mathrm{sec} .\end{array}$ & $\begin{array}{l}50^{\circ} \mathrm{C} \\
1 \mathrm{~min} .\end{array}$ & $\begin{array}{l}72^{\circ} \mathrm{C} \\
1 \mathrm{~min} .\end{array}$ & $\begin{array}{c}72^{\circ} \mathrm{C} \\
10 \mathrm{~min} .\end{array}$ & \\
\hline $\operatorname{csg} \mathrm{D}$ & $\begin{array}{c}\text { TTACCGCCT } \\
\text { GAGATTATC } \\
\text { GT } \\
\text { ATGTTTAAT } \\
\text { GAAGTCCAT } \\
\text { AG }\end{array}$ & 651 & $\begin{array}{l}94^{\circ} \mathrm{C} \\
5 \mathrm{~min} .\end{array}$ & $\begin{array}{c}94^{\circ} \mathrm{C} \\
30 \mathrm{sec} .\end{array}$ & $\begin{array}{c}50^{\circ} \mathrm{C} \\
40 \mathrm{sec}\end{array}$ & $\begin{array}{l}72^{\circ} \mathrm{C} \\
45 \mathrm{sec} .\end{array}$ & $\begin{array}{c}72^{\circ} \mathrm{C} \\
10 \mathrm{~min} .\end{array}$ & $\begin{array}{l}\text { Bhowmick } \\
\text { et al. }(2011)\end{array}$ \\
\hline $\operatorname{fim} \mathbf{H}$ & $\begin{array}{c}\text { TGCAGAACG } \\
\text { GATAAGCCG } \\
\text { TGG } \\
\text { GCAGTCACC } \\
\text { TGCCCTCCG } \\
\text { GTA }\end{array}$ & 508 & $\begin{array}{l}94^{\circ} \mathrm{C} \\
5 \mathrm{~min} .\end{array}$ & $\begin{array}{c}94^{\circ} \mathrm{C} \\
30 \mathrm{sec} .\end{array}$ & $\begin{array}{c}50^{\circ} \mathrm{C} \\
40 \mathrm{sec} .\end{array}$ & $\begin{array}{l}72^{\circ} \mathrm{C} \\
45 \mathrm{sec} .\end{array}$ & $\begin{array}{c}72^{\circ} \mathrm{C} \\
10 \mathrm{~min} .\end{array}$ & $\begin{array}{l}\text { Ghanbarpour } \\
\text { and Salehi, } \\
(2010)\end{array}$ \\
\hline$e a e \mathbf{A}$ & $\begin{array}{c}\text { ATGCTTAGT } \\
\text { GCTGGTTTA } \\
\text { GG } \\
\text { GCCTTCATC } \\
\text { ATTTCGCTT } \\
\text { TC }\end{array}$ & 248 & $\begin{array}{l}94^{\circ} \mathrm{C} \\
5 \mathrm{~min} .\end{array}$ & $\begin{array}{l}94^{\circ} \mathrm{C} \\
30 \mathrm{sec} .\end{array}$ & $\begin{array}{c}51^{\circ} \mathrm{C} \\
30 \mathrm{sec} .\end{array}$ & $\begin{array}{c}72^{\circ} \mathrm{C} \\
30 \mathrm{sec}\end{array}$ & $\begin{array}{l}72^{\circ} \mathrm{C} \\
7 \mathrm{~min} .\end{array}$ & $\begin{array}{l}\text { Bisi-Johnson } \\
\text { et al. (2011) }\end{array}$ \\
\hline $\operatorname{tet} \mathrm{A}(\mathbf{A})$ & $\begin{array}{c}\text { GGTTCACTC } \\
\text { GAACGACGT } \\
\text { CA } \\
\text { CTGTCCGAC } \\
\text { AAGTTGCAT } \\
\text { GA }\end{array}$ & 576 & $\begin{array}{l}94^{\circ} \mathrm{C} \\
5 \mathrm{~min} .\end{array}$ & $\begin{array}{l}94^{\circ} \mathrm{C} \\
30 \mathrm{sec} .\end{array}$ & $\begin{array}{c}50^{\circ} \mathrm{C} \\
40 \mathrm{sec} .\end{array}$ & $\begin{array}{l}72^{\circ} \mathrm{C} \\
45 \mathrm{sec} .\end{array}$ & $\begin{array}{c}72^{\circ} \mathrm{C} \\
10 \mathrm{~min} .\end{array}$ & $\begin{array}{l}\text { Randall et al. } \\
\text { (2004) }\end{array}$ \\
\hline bla TEM & $\begin{array}{l}\text { ATCAGCAAT } \\
\text { AAACCAGC } \\
\text { CCCCGAAGA } \\
\text { ACGTTTTC }\end{array}$ & 516 & $\begin{array}{l}94^{\circ} \mathrm{C} \\
5 \mathrm{~min} .\end{array}$ & $\begin{array}{c}94^{\circ} \mathrm{C} \\
30 \mathrm{sec} .\end{array}$ & $\begin{array}{c}54^{\circ} \mathrm{C} \\
40 \mathrm{sec} .\end{array}$ & $\begin{array}{l}72^{\circ} \mathrm{C} \\
45 \mathrm{sec} .\end{array}$ & $\begin{array}{c}72^{\circ} \mathrm{C} \\
10 \mathrm{~min} .\end{array}$ & $\begin{array}{l}\text { Colom et al. } \\
\text { (2003) }\end{array}$ \\
\hline
\end{tabular}

7. In vitro sensitivity testing using Olive Leaf Extract on isolated E. coli:

All E. coli isolates that showed resistance to antibiotics were subjected for testing the effect of Olive Leaf Extract.

7.1. Extraction of Olive Leaf:

The leaves were purchased from herbal market, cleaned from extraneous matter and properly washed then dried in hot air-oven for $24 \mathrm{~h}$ at $40{ }^{\circ} \mathrm{C}$. The dried leaves were ground in a blender to form powder. Thereafter, $100 \mathrm{~g}$ of the powder were macerated in $1000 \mathrm{ml}$ absolute ethanol $(10 \%$ concentration) and allowed to extract for $48 \mathrm{~h}$
Ahmed and Abolghait (2014) with some modification. The resultant (dark green-brown mixture) was filtered and the filtrate was concentrated in a rotary evaporator under reduced pressure.

7.2. Preparation of filter paper discs from olive leaf extract:

Six millimeter filter paper was used to prepare discs. The discs were then sterilized in by autoclaving. The extract was diluted at different concentrations. A total volume of $250 \mu \mathrm{l}$ was used to soak 50 discs without over or under wetting those Hannan et al. (2008). 
Discs with concentration $10.0 \mathrm{mg}$ per discs were obtained. Prepared discs were stored at $4{ }^{\circ} \mathrm{C}$ in the refrigerator till use. The discs were kept at room temperature for one hour to before use.

Antimicrobial susceptibility testing using filter paper discs from olive leaf extracts according to Finegold and Martin (1982).

\section{RESULTS}

Table 2: Incidence of $E$. coli infection in broiler chickens.
1. Prevalence rate of $E$. coli isolated from examined broilers:

In 100 broiler chickens suffering from ruffled feathers, depression, off food were subjected for P.M. examination, revealed caseous masses on internal organs, cellulitis, entero-colitis and damage intestinal mucosa then examined by bacteriological methods during different seasons of the year, E. coli was recovered from 37 samples with a prevalence rate $37 \%$ (37 out of 100) as shown in Table (2).
Number of examined chicken

100
Number of positive 37

\section{Percentage of positive\%}

37

2. Prevalence of $E$ coli in different chicken organs:

The internal organs of each chicken were examined by bacteriological examination to determine the prevalence of Escherichia coli in each chicken organ as shown in Table (3) where E. coli was isolated as the following $30 \%$ (30 out of 100) from liver; $24 \%$ (24 out of 100) from lung; $20 \%$ (20 out of 100) from caecum; $14 \%$ (14 out of 100) from spleen; $11 \%$ (11 out of 100) from kidney and 9\% (9 out of 100) from heart.

Table 3: Rate of E coli recovery from internal organs.

\begin{tabular}{ccc}
\hline $\begin{array}{c}\text { Examined organs in 100 chicken } \\
\text { 6 organs/ Bird }\end{array}$ & $\begin{array}{c}\text { Percentage of } \\
\text { positive\%* }\end{array}$ & $\begin{array}{c}\text { Percentage of } \\
\text { negative\%* }\end{array}$ \\
\hline Liver & 30 & 70 \\
\hline Lung & 24 & 76 \\
\hline Caecum & 20 & 80 \\
\hline Spleen & 14 & 86 \\
\hline Kidney & 11 & 89 \\
\hline Heart & 9 & 91 \\
\hline Total & $18^{* *}$ & $82^{* * *}$ \\
\hline
\end{tabular}

* calculated according to the number of tested birds (100).

** calculated according to the number of examined samples (600).

\section{E. coli serotypes isolated from examined chickens:}

The isolated $E$. coli were serotyped using polyvalent and monovalent $E$. coli antisera to determine the $E$. coli serotype.
The serotyping of isolated biochemically identified $E$. coli revealed that the most predominant serotypes and the most predominant serogroup were $\mathrm{O}_{125} 6 \%$ \& $\mathrm{O}_{91} 5 \%$ \& $\mathrm{O}_{1} 4 \% \& \mathrm{O}_{26} \mathrm{~K}_{60} 4 \%$ \& $\mathrm{O}_{86} \mathrm{~K}_{64} 3 \%$ \& $\mathrm{O}_{128}$ $2 \%$ \& $\mathrm{O}_{55} \mathrm{~K}_{59} 1 \%$ \& $\mathrm{O}_{166} 1 \%$ \& $\mathrm{O}_{103} 1 \%$ \& $\mathrm{O}_{144} 1 \%$ and 9 strains untypable E. coli $(9 \%)$ as shown in Table (4).

Table 4: E. coli serotypes recovered from bacteriologically examined chickens.

\begin{tabular}{ccc}
\hline The infected $\boldsymbol{E}$ coli serotype & Number of positive chicken & Percentage of positive \% \\
\hline $\mathbf{O}_{\mathbf{1 2 5}} \mathbf{K}$ - & $6 / 37$ & 16 \\
\hline $\mathbf{O}_{\mathbf{9 1}} \mathbf{K}-$ & $5 / 37$ & 14 \\
\hline $\mathbf{O}_{\mathbf{1}} \mathbf{K}$ - & $4 / 37$ & 11 \\
\hline $\mathbf{O}_{\mathbf{2 6}} \mathbf{K}_{\mathbf{4 0}}$ & $4 / 37$ & 11 \\
\hline $\mathbf{O}_{\mathbf{8 6}} \mathbf{K} \mathbf{6 4}$ & $3 / 37$ & 8 \\
\hline $\mathbf{O}_{\mathbf{1 2 8}} \mathbf{K}$ - & $2 / 37$ & 5 \\
\hline $\mathbf{O}_{\mathbf{5 5}} \mathbf{K} \mathbf{5 9}$ & $1 / 37$ & 3 \\
\hline $\mathbf{O}_{\mathbf{1 6 6}} \mathbf{K}$ - & $1 / 37$ & 3 \\
\hline $\mathbf{O}_{\mathbf{1 0 3}} \mathbf{K}$ - & $1 / 37$ & 3 \\
\hline $\mathbf{O}_{\mathbf{1 4 4}} \mathbf{K}$ - & $1 / 37$ & 3 \\
\hline Untypable & $9 / 37$ & 24 \\
\hline Total & 37 & 100 \\
\hline
\end{tabular}


4. Sensitivity of E. coli serotypes to different antibiotic agents:

As shown in Table (5), E. coli $\mathrm{O}$ groups (28) were found to be $100 \%$ resistant to Lincomycin antibiotic followed by Amoxicillin (82.14), Enrofloxacin
(71.73\%), Tetracycline $(67.86 \%)$, Doxycycline (60.71\%), Ampicillin (57.14\%), Flumequine (42.86\%), Gentamycin (32.14\%), Erythromycin (32.14\%), Naldixic acid (28.27\%), Chloramphenicol (25\%), Ciprofloxacin (10.7\%) and Colistin (7.14\%).

Table 5: Sensitivity of E. coli serotypes and to different antibiotic agents.

\begin{tabular}{|c|c|c|c|c|c|c|c|c|c|c|c|c|c|}
\hline & Cl & $\mathbf{L}$ & $\mathrm{C}$ & $\mathrm{CF}$ & ENR & UB & NA & DO & $\mathbf{T}$ & A & $\mathbf{E}$ & $\mathbf{G}$ & Am \\
\hline $\mathbf{R}$ & 2 & 28 & 7 & 3 & 20 & 12 & 8 & 17 & 19 & 16 & 9 & 9 & 23 \\
\hline $\mathbf{S}$ & 25 & $\overline{0}$ & 19 & 23 & 7 & 14 & 18 & 9 & 6 & 10 & 18 & 15 & 3 \\
\hline I & 1 & 0 & 2 & 2 & 1 & 2 & 2 & 2 & 3 & 2 & 1 & 4 & 2 \\
\hline $\begin{array}{l}\text { R: resistant. } \\
\text { CL: Colistin. } \\
\text { CF: Ciprofloxacine. } \\
\text { NA: Nalidixic acid. } \\
\text { A: Amoxycilline }\end{array}$ & & $\begin{array}{l}\text { S: se } \\
\text { L: Li } \\
\text { ENR } \\
\text { DO: } \\
\text { E: E }\end{array}$ & $\begin{array}{l}\text { sitiv } \\
\text { con } \\
\text { Enro } \\
\text { oxy } \\
\text { thro }\end{array}$ & $\begin{array}{l}\text { cine. } \\
\text { loxac } \\
\text { yclin } \\
\text { aycin }\end{array}$ & & $\begin{array}{l}\text { inter } \\
\text { : Chlo } \\
\text { : Flo } \\
\text { : Tetr } \\
\text { : Ger }\end{array}$ & $\begin{array}{l}\text { ediat } \\
\text { amph } \\
\text { equir } \\
\text { cyclir } \\
\text { imyci }\end{array}$ & icol. & & & & & \\
\hline
\end{tabular}
AM: Ampicilline.

\section{PCR Detection of resistant Genes of E. coli:}

PCR using primers fragments listed in materials and methods for amplification of $\operatorname{bla}_{\mathrm{TEM}}$ and $\operatorname{tet} \mathrm{A}(\mathrm{A})$ genes from the isolated $E$. coli strains in this study.

\subsection{Detection of bla ${ }_{T E M}$ gene of E coli:}

bla $a_{\mathrm{TEM}}$ gene responsible for resistant of the isolated E. coli strains to Beta-lactames antibiotics. Our results showed amplification of 516 bp of (bla $\left.a_{\mathrm{TEM}}\right)$ gene from the extracted DNA of all tested E. coli strains (10) as shown in Figure (1)

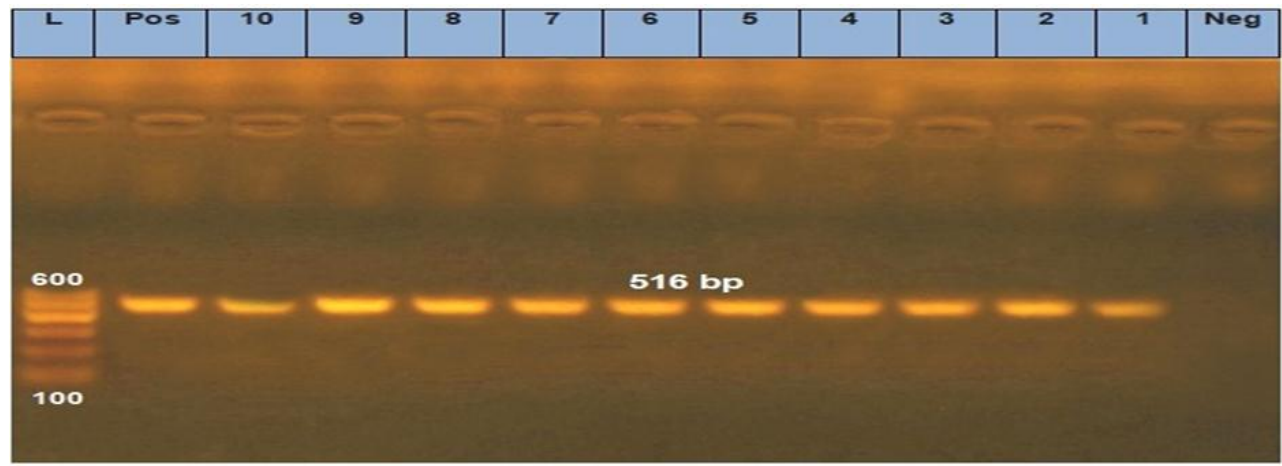

Figure (1) amplification of bla TEM gene of Escherichia coli strains: Amplification of 516 bp was observed in the extracted DNA of $\mathrm{O}_{1}, \mathrm{O}_{26}, \mathrm{O}_{55}, \mathrm{O}_{86}, \mathrm{O}_{91}, \mathrm{O}_{103}, \mathrm{O}_{125}, \mathrm{O}_{128}, \mathrm{O}_{144}$ and $\mathrm{O}_{166}$, (in lane number 1, 2,3, 4, 5, 6, 7, 8, 9,10 , respectively).

\subsection{Detection of tet (A) gene of E. coli:} tetA (A)gene responsible for resistant of the isolated E. coli strains to tetracycline antibiotics. Our results showed amplification of $576 \mathrm{bp}$ of $\operatorname{tet} \mathrm{A}(\mathrm{A})$ gene from the extracted DNA of all isolated E. coli strains except $\mathrm{O}_{55}$ (No. 3) not have this gene as shown in Figure (2)

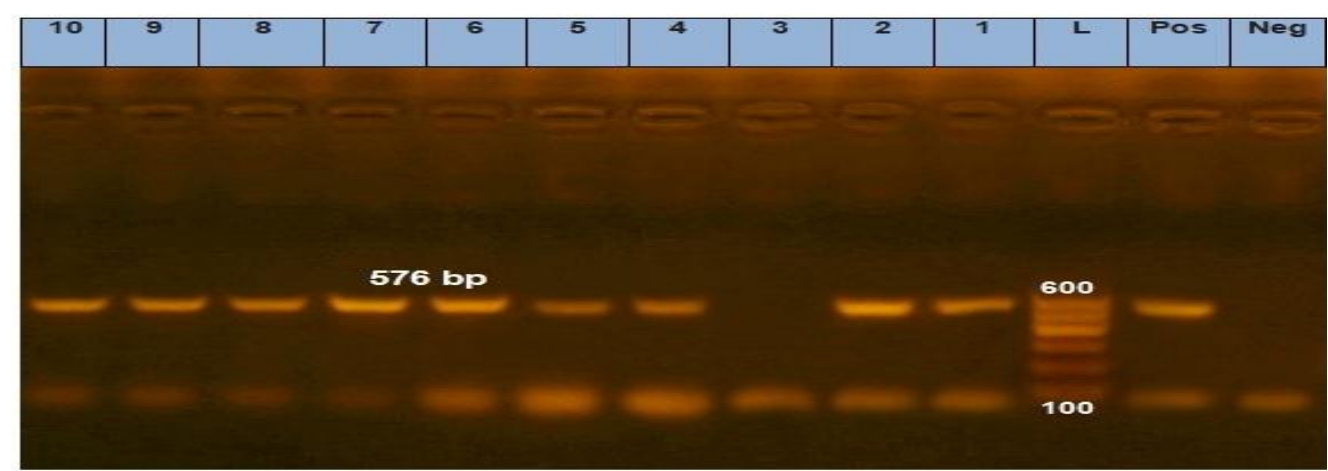

Figure (2) amplification of $\operatorname{tet} \mathbf{A}(\mathrm{A})$ gene of Escherichia coli strains: Amplification of 576 bp was observed in the extracted DNA of $\mathrm{O}_{1}, \mathrm{O}_{26}, \mathrm{O}_{86}, \mathrm{O}_{91}, \mathrm{O}_{103}, \mathrm{O}_{125}, \mathrm{O}_{128}, \mathrm{O}_{144}$ and $\mathrm{O}_{166}$ (in lane number 1, 2, 4, 5, 6, 7, 8, 9 and 10 , respectively). No amplification in $\mathrm{O}_{55}$ (in lane number 3 ). 


\section{PCR for Detection of virulence Genes of E. coli:} PCR using primers fragments listed in materials and methods for amplification of eae A, fim $\mathrm{H}, \operatorname{csg} \mathrm{D}$ and $a d r \mathrm{~A}$ from the isolated $E$ coli strains in this study.

6.1. Detection of eaeA gene of E. coli:
Ettaching and effacing mechanisms gene (eae A) is responsible for attachement and effacing of $E$. coli to the enterocytes of the intestine of chicken. Our results showed amplification of 248 bp of (eae A) gene of all isolated serotypes except $\mathrm{O}_{125}$ (in lane No. 7) from the extracted DNA of $E$ coli strains as shown in Figure (3)

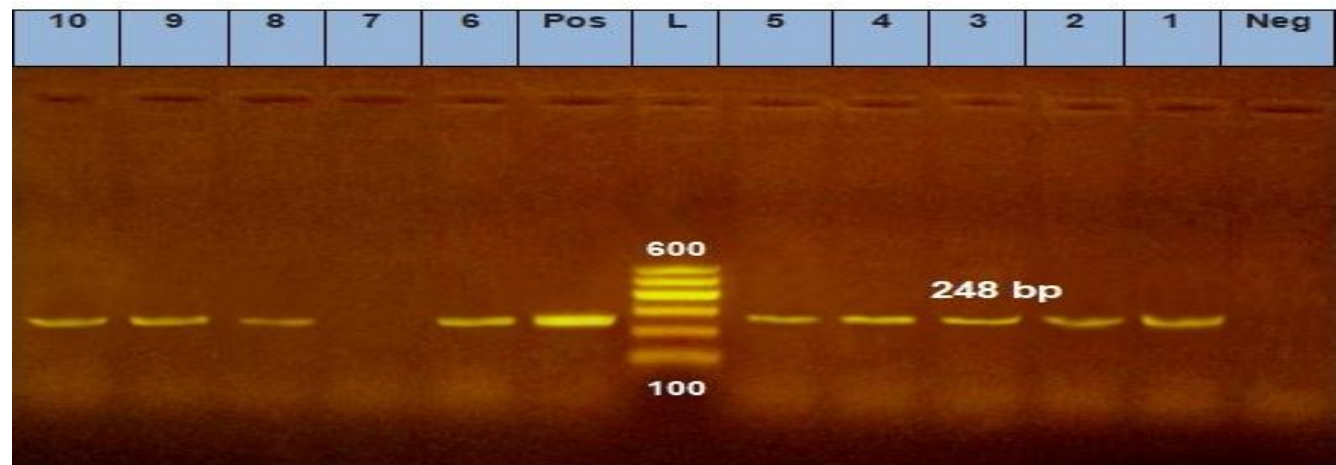

Figure (3) amplification eae A gene of Escherichia coli strains: Amplification of 248 bp was observed in the extracted DNA of $\mathrm{O}_{1}, \mathrm{O}_{26}, \mathrm{O}_{55}, \mathrm{O}_{86}, \mathrm{O}_{91}, \mathrm{O}_{103}, \mathrm{O}_{128}, \mathrm{O}_{144}$ and $\mathrm{O}_{166}$ (in lane number 1, 2,3, 4, 5, 6, 8, 9 and 10, respectively). No amplification in $\mathrm{O}_{125}$ (in lane number 7).

6.2. Detection of fim $\mathrm{H}$ gene of E. coli:

fim $\mathrm{H}$ gene which responsible for adhesion of E. coli. The results showed amplification of 508 bp of fim $\mathrm{H}$ gene of all isolated serotypes from the extracted DNA of E. coli strains as shown in Figure (4).

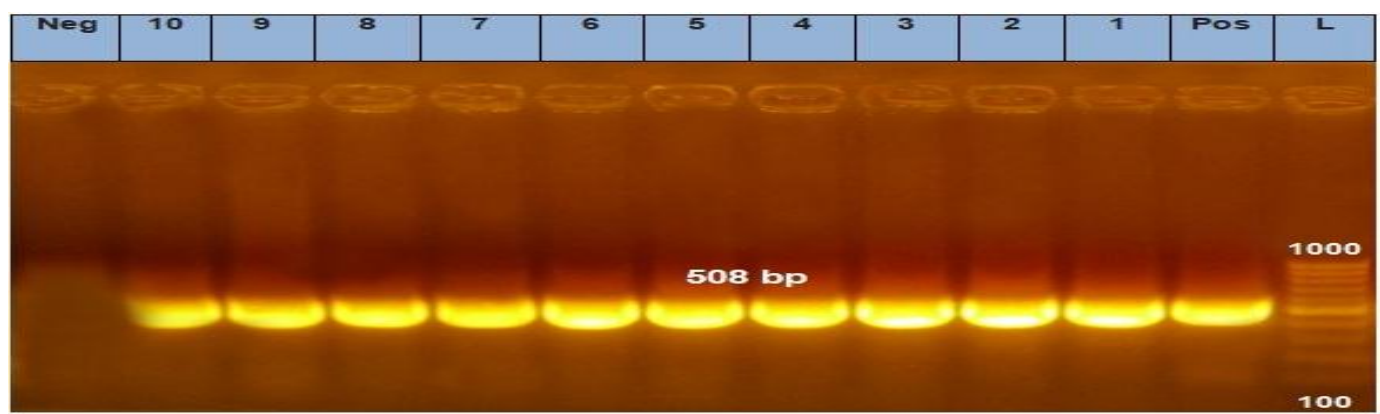

Figure (4) amplification of fim $\mathbf{H}$ gene of Escherichia coli strains: Amplification of 508 bp was observed in the extracted DNA of $\mathrm{O}_{1}, \mathrm{O}_{26}, \mathrm{O}_{55}, \mathrm{O}_{86}, \mathrm{O}_{91}, \mathrm{O}_{103}, \mathrm{O}_{125}, \mathrm{O}_{128}, \mathrm{O}_{144}$ and $\mathrm{O}_{166}$, (in lane number 1, 2,3, 4, 5, 6, 7, 8, 9,10 , respectively).

6.2. Detection of csgD gene of E. coli: $\operatorname{csg} \mathrm{D}$ gene which is the master regulator for adhesive curli fimbriae expression, plays a positive role in biofilm formation of $E$. coli. The results showed amplification of $651 \mathrm{bp}$ of $\operatorname{csg} \mathrm{D}$ gene of all isolated serotypes from the extracted DNA of $E$. coli strains as shown in Figure (5).

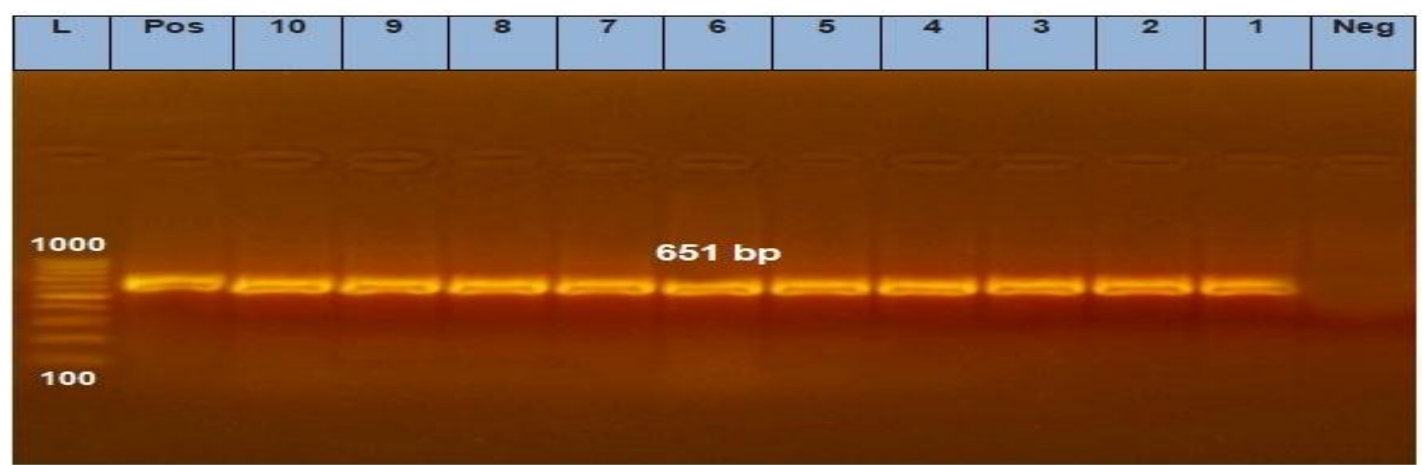

Figure (5) amplification of $\boldsymbol{c s g D}$ gene of Escherichia coli strains: Amplification of 651 bp was observed in the extracted DNA of $\mathrm{O}_{1}, \mathrm{O}_{26}, \mathrm{O}_{55}, \mathrm{O}_{86}, \mathrm{O}_{91}, \mathrm{O}_{103}, \mathrm{O}_{125}, \mathrm{O}_{128}, \mathrm{O}_{144}$ and $\mathrm{O}_{166}$, (in lane number 1, 2,3, 4, 5, 6, 7, 8, 9,10 , respectively). 
6.3. Detection of $a d r$ A gene of $E$. coli: $a d r \mathrm{~A}$ gene which responsible for cellulose synthesis. The results showed amplification of $1113 \mathrm{bp}$ of $a d r \mathrm{~A}$ gene of all isolated serotypes from the extracted DNA of E. coli strains except $\mathrm{O}_{103}$ as shown in Figure (6).

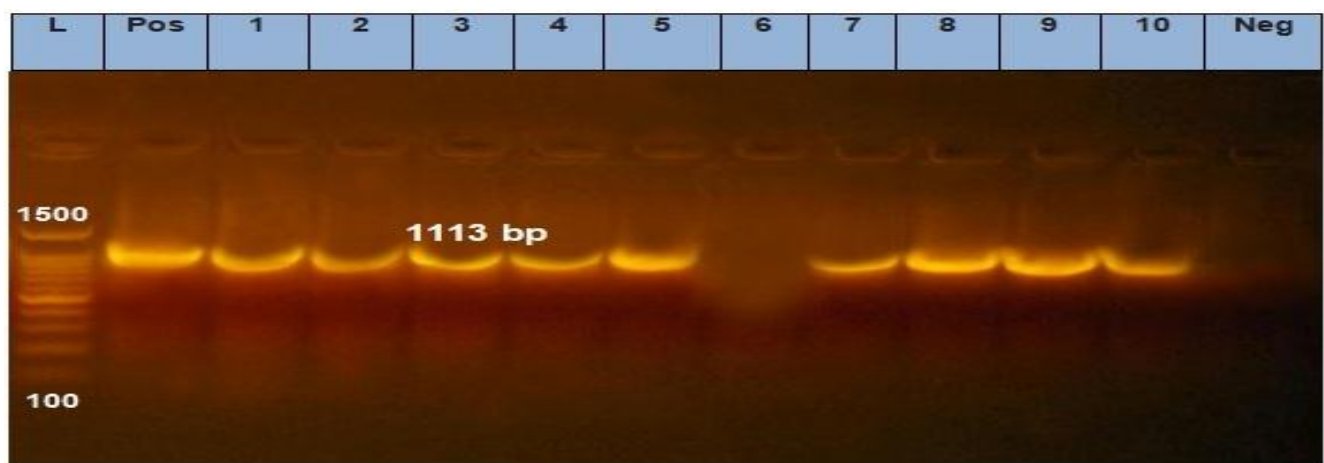

Figure (6) amplification adrA gene of Escherichia coli strains: Amplification of $1113 \mathrm{bp}$ was observed in the extracted DNA of $\mathrm{O}_{1}, \mathrm{O}_{26}, \mathrm{O}_{55}, \mathrm{O}_{86}, \mathrm{O}_{91}, \mathrm{O}_{125}, \mathrm{O}_{128}, \mathrm{O}_{144}$ and $\mathrm{O}_{166}$ (in lane number 1, 2,3, 4, 5, 7, 8, 9 and 10 , respectively). No amplification in $\mathrm{O}_{103}$ (in lane number 6).

\section{Biofilm formation:}

PCR amplifications of $e a e \mathrm{~A}, f i m \mathrm{H}, c s g \mathrm{D}$ and $a d r \mathrm{~A}$ genes from the isolated $E$. coli strains in this study were assayed for biofilm formation in vitro using tube biofilm assay. Result revealed that, all the examined serogroups $\left(\mathrm{O}_{1}, \mathrm{O}_{26}, \mathrm{O}_{55}, \mathrm{O}_{86}, \mathrm{O}_{91}, \mathrm{O}_{103}\right.$, $\mathrm{O}_{125}, \mathrm{O}_{128}, \mathrm{O}_{144}$ and $\mathrm{O}_{166}$ have the ability to make biofilms on the inner walls of the glass tubes after crystal violet staining. On the other hand, no biofilm was observed with negative uninoculated tube.
These results might point to the role that these genes play during expression of proteins involved in biofilm formation.

\section{Effect of olive leaf extract on the multiresistant strains:}

Results of antimicrobial susceptibility testing for 10

$E$. coli serotypes revealed that olive leaf extracts had inhibitory effect at a concentration of $(10 \mathrm{mg})$ on tested serotypes as shown in Figure (7).

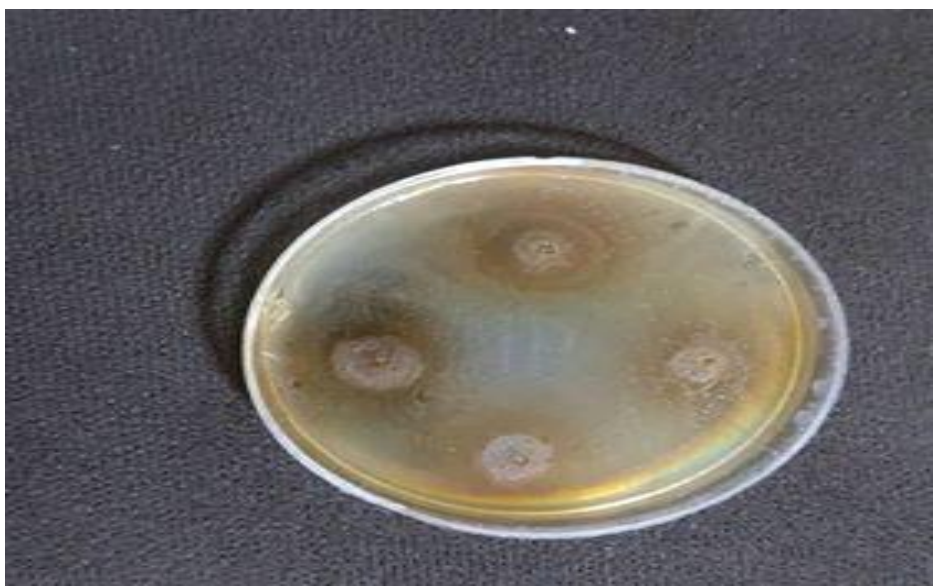

Figure (7): effect of olive leaf extraction E. coli multiresistant strains.

\section{DISCUSSION}

In this study, the incidence of $E$. coli in broiler chickens from Dakahlia governorate was $37 \%$. These results were agreed with that of Robert et al. (2002) and Ružauskas et al. (2010), who isolated E. coli with percentage of $36.8 \%$ and $41.7 \%$, respectively. Higher rates were recorded by El-Sukhon et al. (2002) and Alimehr et al. (1999) who recovered E. coli in $88.2 \%$ and $100 \%$ of the examined samples, respectively.

The obtained results of this study revealed that all the most $E$. coli isolates obtained from liver of the examined chickens followed by lung, caecum, spleen, kidney and heart 30\%, 24\%, 20\%, 14\%, $11 \%$ and 9\%, respectively which agreed with Otaki, 1995 and the explanation of these results is due to infection with APEC generally begins as a localized infection of the air sacs commonly referred as airsacculitis or the air sac disease which in turn may spread to other internal organs resulting in systemic infection Barnes et al. (1999). These results were agreed with Ogunleye et al. (2008) who reported that, the most Escherichia coli isolates obtained from liver $67 \%$ then lung and intestine $10 \%$. Also, Sharada et al. (2010) recovered highest percent of isolates from cases of hepatitis $44.6 \%$, enteritis 
$33.8 \%$, pericarditis $16.9 \%$ followed by air saculitis $7.7 \%$.

More than 1000 E. coli serotypes have been reported but only small percentages have been implicated in poultry diseases Cloud et al. (1985). In this study, 10 E. coli serogroupes were identified in 28 positive samples and the most predominant serogroup were $\mathrm{O}_{125} 16 \%, \mathrm{O}_{91} 14 \%, \mathrm{O}_{1} 11 \%, \mathrm{O}_{26} \mathrm{~K}_{60} 11 \%$ \& $\mathrm{O}_{86} \mathrm{~K}_{64}$ $8 \& \mathrm{O}_{128} 5 \%$ \& $\mathrm{O}_{55} \mathrm{~K}_{59} 3 \%$ \& $\mathrm{O}_{166} 3 \%$ \& $\mathrm{O}_{103} 3 \%$ \& $\mathrm{O}_{144} 3 \%$ and untypable E.coli $(24 \%)$. These results nearly go hand to hand with the previous studies of Abd El Tawab et al. (2015). The occurrence of a specific serotype and its role in disease production depends upon the health status of the birds, climatic conditions, geographical situations and managemental strategies Srinivasan et al. (2013).

The Results for Antibiotic sensitivity showed that most of the isolates were multidrug resistant as they resist at least 3 antibiotics as these results agreed with that reported by Momtaz et al. (2012). E. coli isolates were found to be $100 \%$ resistant to Lincomycin almost similar resistance were detected by Ngeleka et al. (1996) who reported $100 \%$ resistant to lincomycin. Lower rate $39.50 \%$ were detected by Sharada et al. (2010).

The Amoxicillin resistance of the $E$. coli isolates in the present study were $82.14 \%$, these results go hand to hand with the previous studies of Anthonia (2012) who showed $80 \%$ resistant to amoxicillin in free range chickens. On the other hand Salehi and Bonab (2006) reported medium resistance AM 53\% in E. coli isolates from chickens of Colisepticemia.

The present study showed resistance percentages to Enrofloxacin $(71.73 \%)$. Almost similar resistance were detected by Salehi and Bonab (2006), 76\% however less percentages 23\%, 34.8 were detected by Amara et al. (1995) and Alimehr et al. (1999), respectively.

In this study, there was high resistance rate of Tetracycline $(67.86 \%)$ in the isolated E. coli which agreed with earlier reports of Alhaj et al. (2007) and Morad (2013) to these antibiotics $81.4 \%, 85.1 \%$, respectively in chicken isolates and disagreed with those of Kolar et al. (2005) who showed less resistant to tetracycline about $48 \%$.

Also E. coli isolates were found to be resistant to Doxycycline with a percentage of $(60.71 \%)$ which similar to that of Ngeleka et al. (1996) (more than $50 \%$ ) but disagree with the results of Salehi and Bonab (2006), who showed high resistant to Doxycycline (88\%).

The $E$. coli isolates in this study expressed resistance to ampicillin at $(57.14 \%)$ percentage, these results go hand to hand with the previous studies of Akond et al. (2009) who reported that $58 \%$ of E. coli strains isolated from poultry and poultry environment in Bangladesh were resistant to ampicillin on the other hand resistance rate to ampiclllin in this study was higher than those reported by Idrees et al. (2011) from poultry in Pakistan.

In this study, about $(42.86 \%)$ of the isolated E.coli were resistant to Flumequine which represent a lower percentage than those reported by Morad, 2013 and Alimehr et al. (1999) who reported percentage of $81.8 \%$ and $67.5 \%$, respectively.

It was also reported that $32.14 \%$ resistant rate was found to Gentamycin. Lower rate $(0 \%)$ was detected by Momtaz et al. (2012). Higher resistant rates $74.3 \%$ were detected by Alhaj et al. (2007).

This result revealed Erythromycin resistant rate $(32.14 \%)$ in the isolated E. coli however higher level detected in previous studies by Salehi and Bonab (2006) who reported $97 \%$ resistant to Erythromycine.

The present study revealed that $28.27 \%$ of the $E$. coli isolates were resistant to Nalidixic acid. This finding was agreed with those of Johnson et al. (2003) who recorded resistance rates of $(37 \%)$ and disagreed with the results reported by Kmet and Kmetova (2010), (87/85/67 \%) from Escherichia coli isolated from healthy chicken broilers during (2006/2007/2008).

The present study showed intermediate percentage of Chloramphenicol resistant $(25 \%)$ between those of Alhaj et al. (2007) who reported high percentage of resistant $75.7 \%$ and Miles et al. (2006) with low percentage rate $2.9 \%$ from broiler chichens.

However, the level of resistance to ciprofloxacin $(10.7 \%)$ of isolated serotypes observed in this study was similar to that reported by Anthonia, (2012), 12 $\%$ in free range chicken. This low resistance rate may also be associated with the low usage of this drug by poultry farmers.

The highest sensitivity rate detected in this study was to colistin $89.28 \%$. This result agreed with that of Filali et al. (1988) and Amara et al. (1995) who reported that colistin exhibited excellent activity against Escherichia coli isolates.

Among food animals that act as reservoirs of ESBLproducing E. coli, broilers were considered to be the most potent reservoir Pacholewicz et al. (2015).In this study the percentage of bla $a_{\text {TEM }}$ gene from the isolated $E$.coli strains was $100 \%$ (10 out of 10 strains) which nearly go hand with the results of 
Maram (2014) who detected bla $a_{\text {TEM }}$ gene in 18 out of 19 E.coli isolates with $94.73 \%$. But these results disagreed with Ghosh et al. (2017) who obtained lower percentage about $10 \%$ from isolated E. coli.

In recent years, tetracycline resistance has emerged among many pathogenic and nonpathogenic species of bacteria. This resistance is mainly due to different efflux pump and ribosomal protection genes, mostly associated with mobile components such as plasmids or transposons Roberts (2012). Screening of the tetracycline resistance gene showed that tet(A) gene was detected in all isolated $E$. coli strains except $\mathrm{O}_{55}$ not have the gene with a percentage $90 \%$ which nearly agreed with the results reported by Zibandeh et al. (2016), $72.5 \%$ of E. coli isolated from the chickens on the day before slaughter.

virulence-associated genes and pathogenicity islands of bacteria play an important role in the pathogenicity of bacteria and that they are important parameters to clarify the mechanism of bacterial pathogenicity Vandekerchove et al. (2005) and Cheng et al. (2006).

This study showed many different genes which are responsible for virulence and biofilm formation of E. coli. Intimin, an outer membrane protein, encoded by eae A, is a bacterial adhesion molecule that mediates the intimate bacterium host cell interaction characteristic of $\mathrm{A} / \mathrm{E}$ (attaching and effacing) lesions of avian pathogenic E. coli Kilic et al. (2007). In this study, high incidence rate $(90 \%)$ of eaeA gene detection was recorded, as it was detected by PCR in 9 out of the 10 tested isolates and these high results agreed with Ramadan et al. (2016) and disagreed with Kilic et al. (2007) who reported the incidence rate $48 \%$ of the $E$. coli isolates.

Surface virulence factors of the pathogens including different adhesion factors may promote bacterial adhesion and biofilm development Schembri et al. (2003). fim $\mathrm{H}$ consists of a fimbria- associated pilin domin and a mannose binding lactin domin, receptor-ligand specific adhesion is among the most fundamental of biological phenomena in nature. This phenomenon underlies eukaryotic cell-cell or cellsurface attachment, initiates recognition and signaling events, binds bacteria to target cells and mediates biofilm formation on medical implants Aprikian et al. (2007). In this study the prevalence of fim $\mathrm{H}$ gene in the isolated $E$. coli strains was $100 \%$ (10 out of 10 strains) and these results were agreed with the results reported by Trkov et al. (2014) as seventy-four (88.1\%) isolates carried the type 1 fimbriae gene fimH and Ghanbarpour et al. (2011) also reported $96.4 \%$ of fecal isolates positive for fim $\mathrm{H}$ compared to $95 \%$ of isolated E. coli from cases of colibacillosis. The results were disagreed with the results of Eftekharian et al. (2016) who detected less percentage $41.7 \%$ of the intestinal isolates only positive for fim $\mathrm{H}$ gene.

Curli fibers (also known as thin aggregative fimbriae) are a major factor in adhesion to surfaces, cell aggregation, and biofilm formation in many enterobacteria Cookson et al. (2002) and PrigentCombaret et al. (2001). Expression of both curli and cellulose depends on the $c s g \mathrm{D}$ protein Arnqvist et al. (1994) in this study, $100 \%$ of the tested strains have the $\operatorname{csg} \mathrm{D}$ gene which go hand with the results of Wang et al. (2016) in 36 non-O157 Shiga toxinproducing Escherichia coli (STEC) strains.

Cellulose synthesis regulation is a very complex phenomenon. In enterobacteria, this phenomenon involves a AgfD-regulated protein $(a d r \mathrm{~A})$ that contains four $\mathrm{N}$-terminal units of the GGDEF domain. These domains may be involved in the regulation of a second messenger molecule, called cyclic di-guanosine mono phosphate (c-di-GMP), the interaction between the GGDEF domain of $a d r \mathrm{~A}$ and the c-di-GMP molecule could initiate cellulose production Romling (2002). In the present study PCR detection of $a d r$ A gene in the isolates revealed that, all strains had the gene except $\mathrm{O}_{103}$ and this result agreed with that reported by Yin et al. (2018) as present exceeded $75 \%$ among all biofilm producer strains.

The result of in vitro tube biofilm assay revealed that, all the examined serogroups $\left(\mathrm{O}_{1}, \mathrm{O}_{26}, \mathrm{O}_{55}, \mathrm{O}_{86}\right.$, $\mathrm{O}_{91}, \mathrm{O}_{103}, \mathrm{O}_{125}, \mathrm{O}_{128}, \mathrm{O}_{144}$ and $\mathrm{O}_{166}$ have the ability to make biofilms on the inner walls of the glass tubes after crystal violet staining and these results were similar to that of Kot et al. (2016) who reported the ability of $E$. coli strains to make biofilm in $81.1 \%$ of the isolates and differ from the results of Marhova et al. (2010) as biofilms were detected in vitro from $24 \%$ of investigated E.coli strains only.

From the results of PCR for detection of virulence and resistant genes we found that, the more resistant and more virulent strains and biofilm forming strains which disagreed with the results of Pavlickova et al. (2017) who reported that, the highest prevalence of antibiotic resistance was observed in weak biofilm producers. Biofilm formation was not statistically associated with any virulence determinant. In this study we found that, all multi resistant strain were sensitive to olive leaf extract and these results were agreed with the results reported by Liu et al. (2017) who demonstrated that at a concentration of $62.5 \mathrm{mg} / \mathrm{ml}$, OLE almost completely inhibited the growth of $E$. coli, so it will be good for controlling the resistant strains of $E$. coli. 


\section{CONCLUSION}

In this study we found that, all multi resistant strain were more virulent strains also more biofilm forming strains. Moreover, all multi resistant strain were sensitive to olive leaf extract.

\section{REFERENCES}

Abd El Tawab, A.; Ammar, A.; Soad, N. and Reem, $M$. (2015): Prevalence of $E$. coli in diseased chickens with its antibiogram pattern. Benha Veterinary Medical Journal, Vol. 28, NO. 2: 224-230

Ahmed, A. and Abolghait, S. (2014): Antibacterial effect of olive (Olea europaea L.) leaves extract in raw peeled undeveined shrimp (Penaeus semisulcatus). International vet. Journal, 2(1): 53-56.

Akond, M.; Hassan, S.; Alam, S. and Shirin, M. (2009): Antibiotic resistance of Escherichia coli isolated from poultry and poultry environment of Bangladesh. American J. Environ. Sci. 5(1): 47-52.

Alhaj, N.; Marianal, N.; Raha, A. and Ishak, Z. (2007): Prevalence of Antibiotic Resistance among Escherichia coli from Different Sources in Malaysia. International Journal of Poultry Science 6 (4): 293-297.

Alimehr, M.; Sadeghi-Hashjin, G.; Pourbakhsh, A. and Nofouzi, K. (1999): Isolation, Identification and in vitro Susceptibility of Avian Escherichia coli to Selected Fluoroquinolones. Arch. Razi Ins. 50, 77-82.

Amara, A.; Ziani, Z. and Bouzoubaa, K. (1995): Antibiotic resistance of Escherichia coli strains isolated in Morocco from chickens with colibacillosis. Vet. Microbiol., 43: (4) 325-330.

Anthonia Olufunke Oluduro (2012): Antibiotic Resistant Commensal Escherichia coli in Faecal Droplets from Bats and Poultry in Nigeria. Veterinaria Italiana 48(3), 297-308.

Aprikian, P.; Tchesnokova, V.; Kidd, B.; Yakovenko, O.; Yarovoy, V.; Trinchina, E.; Vogel, V.; Thomas, W. and Sokurenko, E. (2007): interdomain interaction in fimh adhesion of Escherichia coli regulates the affinity to mannose, j boil chem, 282, 23437.

Arnqvist, A.; Olse'n, A. and Normark, S. (1994): Dependent growth-phase induction of the csgBA promoter in Escherichia coli can be achieved in vivo by 70 in the absence of the nucleoid-associated protein H-NS. Mol. Microbiol. 13:1021-1032.

Barnes. J. and Gross, B. Colibacillosis. In: Calnek, W.; Barnes, J.; Beard, W.; McDougald. M. and Saifin, M. (1999): editors. Diseases of poultry. Ames: Iowa State University Press. p. 131-41.
Cheng, R.; Sun, C.; Xu, S. and Gao, S. (2006): Prevalence of LEE and HPI Pathogenicity Islands of Escherichia coli Isolates from Weaned Piglets in China. Acta Microbiologica Sinica, 46, 368-372.

Cloud, S.; Rosenberger, K.; Fries, A., Wilson, A., Wilson, A. and Odor, M. (1985): In vitro and in vivo characterization of avian E. coli 1serotypes, metabolic activity and antibiotic sensitivity. Avian Dis., 29(4):1084-1093.

CLSI (2016): Clinical and Laboratory standard Institute, M02- A12, M07- A10, and M11A8.

Colom, K.; Pèrez, J.; Alonso, R.; FernándezAranguiz, A.; Lariňo, E. and Cisterna, R. (2003): Simple and reliable multiplex PCR assay for detection of bla $a_{\mathrm{TEM}}, b a_{\mathrm{SHV}}$ and bla ${ }_{\text {OXA-1 }}$ genes in Enterobacteriaceae. FEMS Microbiology Letters 223, 147-151.

Cookson, A.L.; Cooley, W.A. and Woodward, M.J. (2002): The role of type 1 and curli fimbriae of Shiga toxin-producing Escherichia coli in adherence to abiotic surfaces. Int. J. Med. Microbiol. 292:195-205.

Costerton, W.; Lewandowski, Z.; Caldwell, E.; Korber, R. and Lappin-Scott, M. (1995): Microbial biofilms. In Annual Review of Microbiology, Vol. 49. Ornston, N., Ballows, A., and Greenberg, P. (eds). Palo Alto, CA: Annu Rev Inc, pp. 711-745.

Cruickshank, R.; Duguid, J.; Marmion, B. and Swain, R. (1975): Medical Microbiology "the practice of Medical Microbiology" $12^{\text {th }}$ Ed., Churchill Livingstone, Edinbrough, London and New-York.

Edwards, R. and Ewing, H. (1972): Identification of Enterobacteriacae. Minneapolis, Burgess Publishing Co., PP. 709.

Eftekharian, S.; Ghorbanpoor, M.; Seyfi Abad Shapouri, M.; Ghanbarpour, R.; Jafari, R. and Amani, A. (2016): Frequency of selected virulence-associated genes in intestinal and extra-intestinal Escherichia coli isolates from chicken. Iranian Journal of Veterinary Medicine, 10 (2):91-96

EL-Sukhon, N.; Asad, M. and Al-Attar, M. (2002): Studies on the bacterial aetiology of airsacculities of broilers in Northern and Middle Jordan with special reference to $E$. coli. Avian Dis., 46(3): 605-612.

Filali, E.; Bell, G.; El Houadfi, M.; Huggins, B. and Cook, K., (1988): Antibiotic resistance of Escherichia coli strains isolated from chickens with colisepticaemia in Morocco. Comparative immunology, microbiology and infectious diseases, 11(2), pp. 121-124.

Finegold, M. and Martin, T. (1982): Diagnostic Microbiology. 6th ed., the C.V. Mosby Company, St. Louis, Toronto, London.

Ghanbarpour and Salehi (2010): Determination of Adhesin Encoding Genes in Escherichia coli 
Isolates from Omphalitis of Chicks. American Journal of Animal and Veterinary Sciences 5 (2): 91-96.

Ghanbarpour, R.; Sami, M.; Salehi, M. and Ouromiei, M. (2011): Phylogenetic background and virulence genes of Escherichia coli isolates from colisepticemic and healthy broiler chickens in Iran. Trop Anim Health Prod. 43:153-7.

Ghosh, P.; Mahanti, A.; Samanta, I.; Joardar, S.; Batab Yal, K., Dey, S.; Taraphder, S. and Isore, D. (2017): Occurrence of extendedspectrum cephalosporinase producing Escherichia coli in kuroiler birds. Vet. arhiv 87, 745- 757.

Hannan, A.; Saleem, S.; Chaudhary, S.; Barkaat, M. and Arshad, M. (2008): Anti-Bacterial Activity of Nigella Sativa against Clinical Isolates of Methicillin Resistant Staphylococcus aureus. J Ayub Med Coll Abbottabad; 20(3): 72-74

Idrees, M.; Shah, M.; Michael, S.; Qamar, R. and Bokhari, H. (2011): Antimicrobial Resistant Escherichia coli Strains Isolated from Food Animals in Pakistan. Pakistan J. Zool., vol. 43(2), pp. 303-310.

Jefferson, K. (2004): What drives bacteria to produce abiofilm? FEMS Microbiol. Lett. 236(2), pp.163-73.

Johnson, R.; Murray, C.; Gajewski, A.; Sullivan, M.; Snippes, P.; Kuskowski and A. Smith, E. (2003): Isolation and molecular characterization of nalidixic acid-resistant extraintestinal pathogenic Escherichia coli from retail chicken products. Antimicrob Agents Chemother. 47(7): 2161-8.

Kilic, A.; Ertafi, H.; Muz, A.; Ozbey, G. and Kalender, H. (2007): Detection of the eaeA Gene in Escherichia coli from Chickens by Polymerase Chain Reaction. Turk. J. Vet. Anim. Sci. 31(4): 215-218.

Kmeta, V. and Kmetovab, M. (2010): High Level of Quinolone Resistance in Escherichia coli from Healthy Chicken Broilers. Folia Microbiol. 55 (1), 79-82.

Kolar, M.; Bardon, J.; Sauer, P.; Kesselova, M.; Cekanova, D. and Hejnar, P. (2005): Fluoroquinolone-Resistant Escherichia coli and Proteus mirabilis in Poultry of Middle Moravia, Czech Republic. Acta Vet. Brno, 74: 249-253.

Kot, B.; Wicha, J.; Grużewska, A.; Piechota, M.; Wolska, K. and Obrębska, M. (2016): Virulence factors, biofilm-forming ability, and antimicrobial resistance of urinary Escherichia coli strains isolated from hospitalized patients. Turk J Med Sci, 46: 1908-1914.

Liu, Y.; C. Mckeever, C. and Malik, N. (2017): assessment of the Antimicrobial Activity of
Olive Leaf Extract against Food borne Bacterial Pathogens. Front. Microbiol. 8:113.

Maram, M. Tawakol (2011): Studies on Salmonella on Chicken. M.V.Cs thesis, Bacteriology, Immunology and Mycology Department, Faculty of Vet. Med. Mansoura Univ.

Maram, M. Tawakol (2014): Molecular typing and detection of virulence and antibiotic resistant genes in $E$. coli isolated from chickens. Benha University, Faculty of Veterinary Medicine, pp.101.

Marhova, M.; Kostadinova, S. and Stoitsova, S. (2010): Biofilm-Forming Capabilities of Urinary Escherichia coli Isolates. Biotechnology \& Biotechnological Equipment, 24:sup1, 589-593.

Miles, D.; Mclaughlin, W. and Brown, P. (2006): Antimicrobial resistance of Escherichia coli isolates from broiler chickens and humans. Bmc vet res. Vol: (2) 2-7.

Momtaz, H.; Rahimi, E. and Moshkelani, S. (2012): Molecular detection of antimicrobial resistance genes in $E$. coli isolated from slaughtered commercial chickens in Iran. Veterinarni Medicina, 57 (4): 193-197.

Morad, R. (2013): Antibioresistance Profile of Avian pathogenic Escherichia coli Isolates Recovered from Broiler Chicken Farms with Colibacillosis in Kermanshah Province, Iran. Global Veterinaria 10 (4): 447-452.

Nataro, P. and Kaper, B. (1998): Diarrheagenic Escherichia coli. Clin. Microbiol. Rev., 11: 142-201.

Ngeleka, M.; Kwaga, P.; White, G.; Whittam, S.; Riddell, C.; Goodhope, R.; Potter, A. and Allan, B. (1996): Escherichia coli cellulitis in broiler chickens: Clonal relationships among strains and analysis of virulence-associated factor of isolates from diseased birds. Infect. Immun. 64: 3118-3126.

Ogunleye, A.; Oyekunle, M. and Sonibare, A. (2008): Multidrug resistant Escherichia coli isolates of poultry origin in Abeokuta, South Western Nigeria. Veterinarski Arhiv78 (6), 501-509.

Otaki, Y. (1995): Poultry disease control programme in Japan. Asian Livestock, 20, 65-67.

Pacholewicz, E.; Liakopoulos, A.; Swart, A.; Gorte Maker, B.; Dierikx, C.; Havelaar, A. and Schmitt, H. (2015): Reduction of extendedspectrum- $\beta$ lactamase- and AmpC- $\beta$ lactamase-producing Escherichia coli through processing in two broiler chicken slaughterhouses. Int. J. Food. Microbiol. 215, 57-63.

Pavlickova, S.; Klancnik, A.; Dolezalova, M.; Mozina, S. and Holko, I. (2017): Antibiotic resistance, virulence factors and biofilm formation ability in Escherichia coli strains isolated from chicken meat and wildlife in the 
Czech Republic. Journal of environmental science and health, part b, Vol (52).

Prigent-Combaret, C.; Brombacher, E.; Vidal, O.; Ambert, A.; Lejeune, P.; Landini, P. and Dorel, C. (2001): Complex regulatory network controls initial adhesion and biofilm formation in Escherichia coli via regulation of the $\operatorname{csg} \mathrm{D}$ gene. J. Bacteriol. 183: 7213-7223.

Quinn, J.; Markey, K.; Carter, E.; Donnelly, J. and Leonard, C. (2002): Veterinary Microbiology and Microbial Diseases. Black well scientific publications, Oxford, London.

Ramadan, H.; Awad, A. and Ateya, A. (2016): Detection of phenotypes, virulence genes and phylotypes of avian pathogenic and human diarrheagenic Escherichia coli in Egypt. $J$ Infect Dev Ctries, 10(6): 584-591.

Robert, H.; John, K.; Pawin, P.; Keiko, H. and Christina, Z. (2002): Prevalence of Salmonella and E. coli, and Their Resistance to Antimicrobial Agents, In Farming Communities in Northern Thailand. Southeast Asian J Trop Med Public Health. Vol (33): 120-126.

Roberts, C. (2012): Antibiotic Discovery and Development. Acquired Tetracycline Resistance Genes. Springer, pp. 543-568.

Römling, U. (2002): Molecular biology of cellulose production in bacteria. Research in Microbiology 153: 205-212.

Ružauskas, M.; Šiugždinienè, R.; Krikštolaitis, R.; Virgailis, M. and Zienius, D. (2010): Prevalence and Antimicrobial Resistance of E. coli Isolated from Chicken Liver Sold in Retail Markets. Vet. Med. Zoot. T. 52 (74) 67-72.

Salehi, Z. and Bonab, F. (2006): Antibiotics Susceptibility Pattern of Escherichia coli Strains Isolated from Chickens with Colisepticemia in Tabriz Province, Iran. International Journal of Poultry Science 5 (7): 677-684

Schembri, A.; Givskov, M. and Klemm, P. (2002): An attractive surface: gram-negative bacterial biofilms. Sci STKE, RE6.

Schembri, M.; Kjaergaard, K. and Klem, P. (2003): global gene expression in Escherichia coli biofilms. Mol microbial, (48): 253-267.

Sharada, R.; Ruban, S. and Thiyageeswaran, $M$. (2010): Isolation, Characterization and
Antibiotic Resistance Pattern of Escherichia coli Isolated from Poultry. AmericanEurasian Journal of Scientific Research 5(1): 18-22.

Srinivasan, P.; Balasubramaniam, G.; Murthy, T. and Balachandran, $P$. (2013): Bacteriological and pathological studies of egg peritonitis in commercial layer chicken in Namakkal area. Asian Pac J Trop Biomed, 3(12): 988-994.

Swayne, D.; Charman, E.; Glisson, J.; Jackwood, M.; Pearson, E. and Reed, M. (1998): Colibacillosis: A laboratory manual for the Isolation and identification of avian pathogens, fourth edition. Am. Assoc. Avian Pathol. 14-16.

Trkov, M.; Rupel, T.; Bertok, D.; Trontelj, S.; Avgustin, G. and Ambro, J. (2014): Molecular Characterization of Escherichia coli Strains Isolated from Different Food Sources. Food Technol. Biotechnol. 52 (2) 255-262.

Vandekerchove, D.; Vandemaele, F.; Adriaensen, C.; Zaleska, M.; Hernalsteens, P.; De Baets, L.; Butaye, P.; Van Immerseel, F.; Wattiau, P.; Laevens, H.; Mast, J.; Goddeeris, B. and Pasmans, F. (2005): Virulence-Associated Traits in Avian Escherichia coli: Comparison between Isolates from Colibacillosis-Affected and Clinically Healthy Layer Flocks. Veterinary Microbiology, 108, 75-87.

Wang, J.; Stanford, K.; Mcallister, T.; Johnson, R.; Chen, J.; Hou, H.; Zhang, G. and Niu, Y. (2016): Biofilm Formation, Virulence Gene Profiles, and Antimicrobial Resistance of Nine Serogroups of Non-O157 Shiga ToxinProducing Escherichia coli. Foodborne Pathogens and Disease Vol. 13, No. 6

Yin, B.; Zhu, L.; Zhang, Y.; Dong, P.; Mao, Y.; Liang, R.; Niu, L. and Luo, X. (2018): The characterization of biofilm and detection of biofilm related genes in Salmonella isolated from beef processing plants. Foodborne pathogens and disease, Vol. 15, No. 10

Zibandeh, S.; Sharifiyazdi, H.; Asasi, K. and AbdiHachesoo, B. (2016): Investigation of tetracycline resistance genes in Escherichia coli isolates from broiler chickens during a rearing period in Iran. Veterinarski Arhiv 86 (4), 565-572. 


\title{
تقييم العلاقه بين جينات الضراوة والمقاومة للمضادات الحيوبه وتكوين البيوفيلم فى الايشيريشيا كولاى

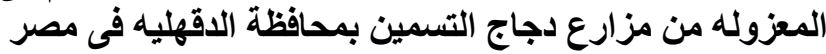

\author{
مرام محمد توكل ، احلام بيزنس
}

E-mail: maram_salah82@hotmail.com_Assiut University web-site: www.aun.edu.eg

تم تجميع . 1 دجاجة تسمين من مز ارع مختلفة تقع في محافظة الدقهلية. خضعت جميع العينات لفحص الاعر اض الاكلينيكية و الصفه

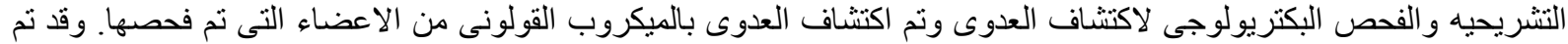

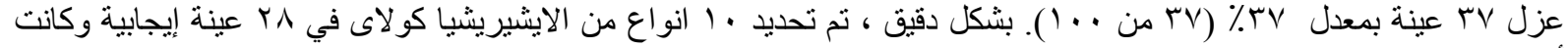
أكثر الانواع هي

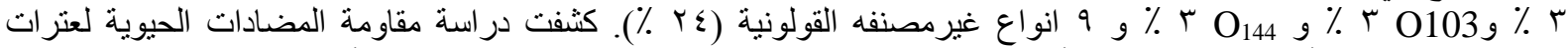

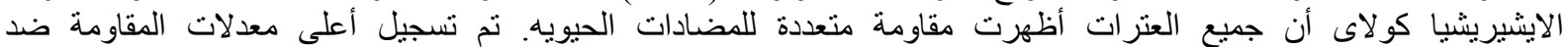

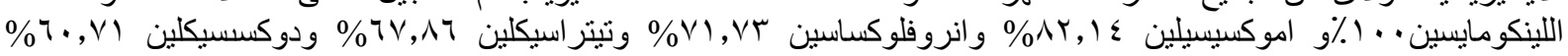

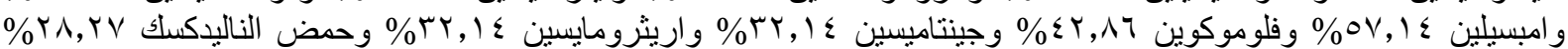

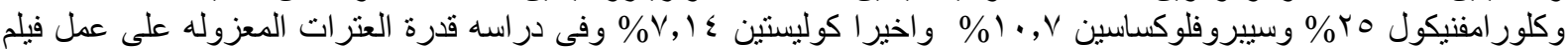

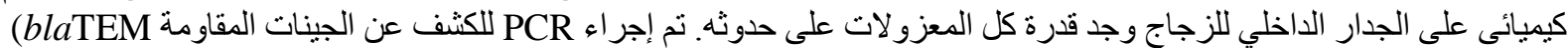

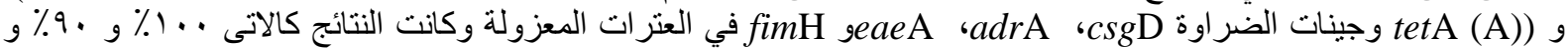

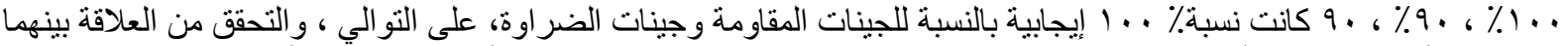

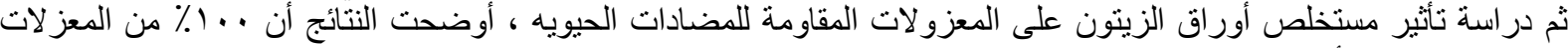

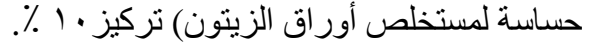

